\title{
Heavy daily-rainfall characteristics over the Gauteng Province
}

\author{
LiesI L Dyson* \\ Department of Geography, Geoinformatics and Meteorology, Geography Building 2-12, University of Pretoria, Pretoria 0001, South Africa
}

\begin{abstract}
Daily rainfall over the Gauteng Province, South Africa, was analysed for the summer months of October to March using 32-yr (1977 to 2009) daily rainfall data from about 70 South African Weather Service stations. The monthly and seasonal variation of heavy rainfall occurrences was also analysed. Three 24-h heavy rainfall classes are defined considering the area-average rainfall. A significant rainfall event is defined when the average rainfall exceeds $10 \mathrm{~mm}$, a heavy rainfall event when the average rainfall exceeds $15 \mathrm{~mm}$ and a very heavy rainfall event when the average rainfall exceeds $25 \mathrm{~mm}$. January months have the highest monthly average rainfall as well as the highest number of heavy and very heavy rainfall days. The month with the second-highest number of heavy and very heavy rainfall days is February followed by March and October. December has the second-highest monthly average rainfall and the most days with rain. However, it is also the month with the lowest number of heavy and very heavy rainfall days. The highest 24-h rainfall recorded at a single station during the 32-yr period was $300 \mathrm{~mm}$ in December 2006. However, rainfall exceeding $115 \mathrm{~mm}$ at a single rainfall station in the Gauteng Province is very rare and does not occur every year. January months receive these events more than any other month but this only transpires in approximately a third of years. The central and north-western parts of the Province experience the most events where the rainfall at a single station surpasses 75 and $115 \mathrm{~mm}$. With regard to seasonal rainfall, the 1995/96 summer rainfall season had the highest seasonal rainfall during this 32-yr period followed by the 1999/2000 season. The 1995/96 season had above normal rainfall in both early and late summer but the 1999/2000 season was dry in early summer and very wet in late summer. Significantly high seasonal rainfall is associated with above-normal rainfall in late summer.
\end{abstract}

Keywords: widespread heavy rainfall, Gauteng, daily rainfall, weather forecasting, summer rainfall, climatology of heavy rainfall

\section{Introduction}

Rainfall resulting in flooding occurs from time to time over the Gauteng Province. The heavy rainfall events may take place over most of the province and last for days, resulting in widespread flooding and disruption of infrastructure and even loss of life. Examples of such events took place during January and February 1996 (De Coning et al., 1998) and February 2000 (Dyson and Van Heerden, 2001). However, heavy rainfall may also occur in isolated areas over the Gauteng Province from so called mesoscale weather systems, resulting in flash flooding. In these instances the heavy rainfall may be of a short duration (but intense) and is often associated with strong winds and hail (Viviers and Chapman, 2008; Ngubo et al., 2008).

Gauteng Province (hereafter Gauteng) is situated on the interior plateau of South Africa and receives most of its rainfall in summer. The annual average rainfall in Gauteng varies between just over $700 \mathrm{~mm}$ on the Witwatersrand (approximately $1700 \mathrm{~m} \mathrm{a} . \mathrm{m}$. s. 1.) and just over $600 \mathrm{~mm}$ north of the Magaliesberg (approximately $1100 \mathrm{~m}$ a. m. s. 1.) (SAWS,1998). Most of Gauteng falls into the climate region: Moist Highveld Grassland, and is relatively cool with average annual maximum temperatures of about $22^{\circ} \mathrm{C}$ in the south but increasing to $25^{\circ} \mathrm{C}$ in the north. There are about $100 \mathrm{~d}$ with rain in Johannesburg and 85 in Pretoria (Kruger, 2004). The extreme northern parts of Gauteng fall into the Central Bushveld climate region.

* To whom all correspondence should be addressed

욜 +2712 420 2469; fax: +27 (0)86 6592154; e-mail: liesl.dyson@up.ac.za

Received 9 February 2009; accepted in revised form 26 August 2009.
According to Kruger (2004) the maximum rainfall over Gauteng occurs during the December and January months.

Gauteng is responsible for over a third of South Africa's Gross Domestic Product (GDP) and a tenth of Africa's GDP. Geographically, Gauteng is the smallest province in South Africa, covering approximately $16500 \mathrm{~km}^{2}$, but nearly $20 \%$ (9.6 m.) of South Africa's population reside in Gauteng. It is estimated that Gauteng will be home to $14.6 \mathrm{~m}$. people by 2015. There were 405 informal settlements in Gauteng in 2006 (Gauteng Department of Housing, 2006); the overcrowding in these settlements has reached extreme proportions with as many as 24 people sharing a living space of approximately $40 \mathrm{~m}^{2}$ (Beavon, 2004). The vacant land on the river banks in the informal settlements has also become populated by shacks and these communities are especially vulnerable to flash flooding. This study focuses on Gauteng due to its importance to the economy of South Africa and its high population density, but also due to the availability of observed meteorological data in the province. In addition it is also one of the regions for which weather forecasts are issued on a daily basis.

In an attempt to understand more about the characteristics of heavy rainfall over Gauteng, observed daily rainfall data were analysed for the summer months (October-March) for a period of 32 years. In this paper early summer refers to October to December and late summer to January to March. The rainfall at individual stations is investigated, but the emphasis is on the areal average rainfall over Gauteng. One of the forecasting challenges for Gauteng is that the type of weather system responsible for precipitation, and indeed heavy rainfall, differs considerably from early to late summer. During early summer the atmosphere has a distinct extra-tropical nature when weather systems such as cut-off lows are frequent (Singleton 
and Reason, 2007). However, in late summer (January and February) tropical circulation systems are much more prevalent over South Africa (Dyson and Van Heerden, 2002). In this paper the emphasis is not on the weather systems responsible for the heavy rainfall but rather concentrates on rainfall statistics over Gauteng. The results from this paper form the basis of ongoing research investigating the atmospheric variables and synoptic circulation patterns associated with heavy rainfall over Gauteng.

An example of heavy rainfall 'climatology' in the scientific literature is by Maddox et al. (1979), who described aspects of flash flooding over the USA. More recently, Brooks and Stensrud (2000) created an hourly rainfall climatology over the USA, followed by Schumacher and Johnson (2006), who described characteristics of extreme rain events over the eastern two-thirds of the United States. They found that extreme rain events (where the 24-h precipitation total at 1 or more stations exceeds the 50 -yr recurrence amount for that location) are most common in July, and that in the northern USA these events transpire almost exclusively in the warm season. They also concluded that most of these events $(66 \%)$ are associated with mesoscale convective systems while synoptic and tropical systems play a larger role in the south and east. Chen et al. (2007) used a similar statistical approach to investigate heavy rainfall in Taiwan. They found that heavy rainfall occurs with a pronounced afternoon maximum over Taiwan and that the orographic effects are important in determining the spatial distribution of heavy rainfall.

A better understanding and knowledge of the climatology of heavy rainfall will facilitate the forecasting of these extreme events. The main aim of this paper is to make weather forecasters aware of how likely heavy rainfall events are over Gauteng during a particular summer month. Understanding the spatial and temporal distribution of heavy rainfall events is a key aspect in furthering this aim. As flood-producing heavy rainfall events are infrequent, knowledge of the climatology of these events could therefore also aid inexperienced weather forecasters, by providing guidance as to how likely heavy rainfall might be during a particular time of the year.

The data used in this analysis are discussed first and some of the problems encountered in the dataset are highlighted. Information is consequently supplied about the seasonal, monthly and daily rainfall characteristics in Gauteng. Three different heavy rainfall classes are defined for average daily Gauteng rainfall and the monthly characteristics of these events are examined. Lastly, heavy rainfall characteristics at individual stations are discussed for each of the summer months.

\section{Data and methods}

Daily rainfall data were obtained from the South African Weather Service (SAWS) for all summer months (October to March) from 1977 to 2009. SAWS rainfall stations report 24-h accumulated rainfall in the morning (0800 South African Standard Time). All the rainfall stations over Gauteng were investigated for their suitability for use in this analysis. Only stations where data were available for at least $75 \%$ of the period were considered. There were 58 stations with a record length spanning between $90-100 \%$ of the period and another 10 stations with record lengths between $75-90 \%$. However, data from selected rainfall stations with records spanning shorter parts of the period were also included. This was done mainly to capture data in cases where rainfall stations were replaced by new stations, with only slightly different locations, within the period under consideration. An example is the rainfall station

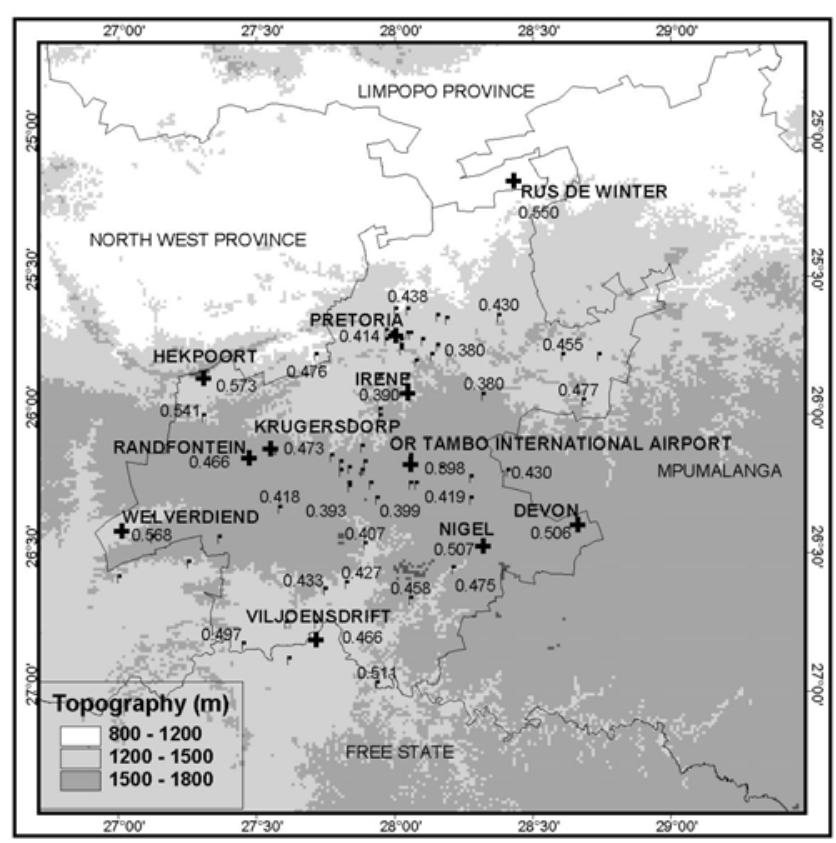

Figure 1

The location of the rainfall stations over the Gauteng Province utilised in the study. The shading indicates height (in m) a. m. s. I. The numerical values are the weights assigned to each of the rainfall stations in the calculation of the area-average rainfall.

at OR Tambo International Airport which closed on the 31 May 1989 while another station opened on 1 June 1989 at almost the same location. Data from both these stations were then used in the analysis. Data for 5 locations were combined in this way resulting in a total number of 73 stations available for analysis over Gauteng. Not all of the rainfall stations were operational every day (i.e., there are discontinuities within the time series of some stations) and consequently the number of rainfall stations which were available for analysis varied between 55 and 73 on any given day within the 32-yr period.

Figure 1 depicts the location of the SAWS rainfall stations over Gauteng. The rainfall stations are generally spatially welldistributed throughout the province, with the exception being the north-eastern extremes where no rainfall stations were available. There is a higher concentration of rainfall stations in the major metropolitan areas of Gauteng (Pretoria in the north and Johannesburg, about $50 \mathrm{~km}$ from Pretoria to the south).

\section{Quality control of rainfall data}

The quality of the rainfall data used, especially in such a large dataset, is of significant concern, and a considerable amount of time was spent performing quality control on the data. Some obvious errors were easy to identify and were removed from the data set. However there were some questionable data values where it was close to impossible to determine the reliability of the observations. The raw rainfall data from SAWS include possible error information, with the daily rainfall values labelled as 'Normal', or 'Error' or 'Accumulated' (if accumulated over more than $1 \mathrm{~d}$ ). If the rainfall value was labelled anything other than Normal it was not used in the analysis for that particular day. As this research focuses on heavy rainfall it was important to have confidence in the high 24-h rainfall values. Brooks and Stensrud (2000) explain how difficult it is to distinguish between 'rare interesting' rainfall events and 'bad data', as these often look similar. Therefore all rainfall events 
where 24-h rainfall at a specific station exceeded $115 \mathrm{~mm}$ were investigated for possible errors. As will be explained later, $115 \mathrm{~mm}$ was identified as a 'single very heavy rainfall event' and represents the $99^{\text {th }}$ percentile of daily maximum rainfall over Gauteng. It does happen from time to time that rainfall which was accumulated is not identified as such in the raw data set. This was relatively easy to identify in the data set when there was missing data for 1 or more days followed by a day reporting very high rainfall. This high rainfall value was then rejected only after comparison with rainfall from surrounding stations, in the process discussed below.

A 2nd set of errors removed from the data was all the cases where a station reported very heavy rainfall for several days in a row while there was no indication from surrounding stations that this did indeed occur. When rainfall at any station over Gauteng exceeded $115 \mathrm{~mm}$ on any particular day, the rainfall values at other stations over Gauteng were also analysed. If there were other stations reporting significant rainfall on that day or if there was a high percentage of rainfall stations over Gauteng reporting rainfall the value was accepted as correct. The last error check was to compare the events remaining, after the elimination of events considered by the previous checks, against other meteorological data and journals such as the SAWS newsletters and website and archived Meteosat $2^{\text {nd }}$ Generation data. This was done in order to identify if there was a physical cause for a heavy rainfall event to occur. The real difficulty was in attempting to detect errors in the much larger number of rainfall events where the daily rainfall at a single station was more than $50 \mathrm{~mm}$ but did not exceed $115 \mathrm{~mm}$ (later defined as a 'single significant rainfall event'). There were too many of these events to hand-check and it would be difficult to determine the accuracy as there were no other data with which to compare it. It is therefore possible that the daily rainfall dataset created as part of this research does contain some errors which may have led to some inaccuracies in the results. However, the impact of this would be limited as the research focused on the heavy rainfall events.

\section{Calculation of average daily rainfall}

Using the rainfall data from the selected stations, an average daily rainfall value for Gauteng was calculated. Additionally, the percentage of rainfall stations recording more than $0 \mathrm{~mm}$ of rainfall was calculated and the highest rainfall measured at any of the stations was also noted. The average Gauteng rainfall was computed using a weighted average method proposed by Tennant and cited in Marx et al. (2003). This method takes the geographical position of each station relative to the other stations into consideration. The following weighting function was applied to the daily rainfall values of all the stations:

$$
W g t=\frac{\sum_{m=1}^{N-1} r_{m}}{(N-1) r_{\max }}
$$

where:

$$
\begin{aligned}
& \text { Wgt }=\text { weight assigned to station } \\
& \sum_{m=1}^{N-1} r_{m}=\begin{array}{l}
\text { sum of the distance between the specific station } \\
\text { and all other stations }
\end{array} \\
& r_{\max }=\begin{array}{l}
\text { maximum distance between the specific station } \\
\text { and any other station }
\end{array} \\
& N \quad=\quad \text { total number of stations }
\end{aligned}
$$

When rainfall stations are distributed evenly over an area, this method renders results which are very close to the mathematical average (the total rainfall at all the stations divided by the number of rainfall stations). The use of the weighting method becomes important when the rainfall stations are not distributed evenly over an area, as is the case for Gauteng. A rainfall station which is geographically distant (close) to other stations will have a larger (smaller) weight factor and will therefore contribute more (less) in the computation of the average rainfall. The stations with the largest weights were over the western extremes of Gauteng (Fig. 1). Hekpoort in the north-west had a weight of 0.573 and Welverdiend in the south-west 0.568 . Other stations with weights larger than 0.5 were Rus De Winter in the extreme north $(0.55)$ and Devon $(0.506)$ and Nigel (0.507) in the south-east. These stations contributed more to the calculation of the average rainfall than the stations over central Gauteng such as Irene (0.390), Pretoria (0.414) and OR Tambo International Airport (0.398). The results from the 2 averaging methods are very similar to those of the weighted average method, generally giving slightly higher daily average values. Of the $5673 \mathrm{~d}$ analysed, the weighted average method produced higher (lower) values than the mathematical average on 753 (560) d. The largest difference occurred on 27 January 1978 when the weighted average was $67 \mathrm{~mm}$ and the mathematical average $59 \mathrm{~mm}$. This was a particularly wet day as 23 stations measured more than $50 \mathrm{~mm}$ of rain and 11 more than $115 \mathrm{~mm}$. Stations over western Gauteng in particular measured high rainfall values, e.g. Randfontein $(100 \mathrm{~mm})$, Krugersdorp $(116 \mathrm{~mm})$ and Hekpoort $(66 \mathrm{~mm})$. From Fig. 1 one can see that these stations also have higher weights in the calculation of the average and therefore the weighted average was higher than the mathematical average for this day. On 18 December 2006 the weighted average rainfall was $18 \mathrm{~mm}$ but the mathematical average was $23 \mathrm{~mm}$. On this day there were only 4 stations with rainfall of more than $50 \mathrm{~mm}$ over southern Gauteng, but with $300 \mathrm{~mm}$ at Viljoensdrift. Due to the isolated nature of the heavy rainfall, the weights assigned to the stations resulted in the weighted average being lower than the mathematical average; the influence of the extreme rainfall at a single station is therefore de-emphasised.

The average Gauteng daily rainfall was henceforth used to calculate the average Gauteng monthly rainfall and the data standardised in order to identify wet and dry months. Moreover, the rainfall at the individual rainfall stations was investigated in order to identify those locations in Gauteng where heavy rainfall occurs most frequently. This was done by dividing Gauteng into eight $0.5^{\circ}$ by $0.5^{\circ}$ grid boxes and calculating the number and percentage of stations that exceeded certain thresholds for each grid box for each 24-h period considered.

\section{Defining heavy rainfall}

An extreme precipitation event is usually defined by using a daily amount exceeding a certain threshold (Zhang et al., 2001). However, different threshold values apply for different parts of the world. One approach is to define heavy rainfall by considering when the areal average rainfall exceeds a particular threshold. For example, Houze et al. (1990) define a 'major rain event' as one in which more than $25 \mathrm{~mm}$ rain falls over an area greater than $12500 \mathrm{~km}^{2}$ in $24 \mathrm{~h}$. In a South African study, Poolman (contributing to Dyson et al., 2002) defines a heavy rainfall event when more than $25 \mathrm{~mm}$ occurs in $24 \mathrm{~h}$ in an area of at least $20000 \mathrm{~km}^{2}$.

The Gauteng Province is approximately $16500 \mathrm{~km}^{2}$ in size. When the average daily rainfall is at least $25 \mathrm{~mm}$ over Gauteng 
it would fall into the major rain event definition provided by Houze et al. (1990). However, analysis of the daily average rainfall data over Gauteng for the 32-yr period reveals that $25 \mathrm{~mm}$ is exceeded only $1 \%$ of the time. Over the 32-yr period the daily average rainfall exceeded $25 \mathrm{~mm}$ on only 65 occasions. In order to capture $10 \%$ of the heaviest rainfall events, a 'significant rainfall event' is defined here by using the $90^{\text {th }}$ percentile, which is $9 \mathrm{~mm}$. A further classification is made, with a 'heavy rainfall event' defined as the $95^{\text {th }}$ percentile, in this case $13 \mathrm{~mm}$, and a 'very heavy rainfall event', similar to Houze's major rain event, when average daily rainfall exceeds $26 \mathrm{~mm}$. However as these thresholds may be applied in an operational environment they were adjusted slightly to fall in line with thresholds commonly used in the forecasting offices. Therefore a 'significant rainfall event' is classified as rainfall exceeding $10 \mathrm{~mm}$, a 'heavy rainfall event' when the rainfall exceeds $15 \mathrm{~mm}$ and a 'very heavy rainfall event' when the rainfall exceeds $25 \mathrm{~mm}$.

Extreme precipitation events are often defined by referring to the rainfall from individual stations. Bradley and Smith (1994) define extreme rainstorms as a 'major rain event' when the daily rainfall accumulation is at least $125 \mathrm{~mm}$ at 1 or more rainfall stations. However, Chen et al. (2007) define a heavy rainfall event in Taiwan when more than $50 \mathrm{~mm}$ occurs in $24 \mathrm{~h}$ at 1 or more weather stations and an extremely heavy rain event when $130 \mathrm{~mm}$ occurs in $1 \mathrm{~d}$ (Chen and $\mathrm{Yu}, 1988$ ). In a recent study Fragoso and Tildes Gomes (2008) identified an extreme rainfall event over southern Portugal when $40 \mathrm{~mm}$ occurred in $24 \mathrm{~h}$.

Zhang et al. (2001) define heavy rainfall separately for different stations in Canada by identifying a threshold value that is exceeded by an average of 3 events per year. They also discuss the characteristics of heavy rainfall by examining the $90^{\text {th }}$ percentile of daily rainfall and the 20 -yr return values. Extreme rain events in the U.S. were identified when rainfall at 1 or more rain gauge reported a 24 -h rainfall total greater than the 50-yr recurrence amount. This spatially-varying threshold is most relevant to identify truly extreme events for this location (Schumacher and Johnson, 2006).

The maximum daily rainfall which occurred at any station over Gauteng was identified for all summer months. Following the definition for the areal average rainfall the $90^{\text {th }}(59 \mathrm{~mm})$, $95^{\text {th }}(75 \mathrm{~mm})$ and $99^{\text {th }}(113 \mathrm{~mm})$ percentile of these values was used to identify a heavy rainfall event at an individual station. However, the forecasters at SAWS issue advisories and warnings for heavy rainfall when more than $50 \mathrm{~mm}$ of rain is expected at any location (Rae, 2008). Therefore a 'single significant rainfall' event is defined when the rainfall at any rainfall station exceeds $50 \mathrm{~mm}$. A 'single heavy rainfall' event is when the rainfall exceeds $75 \mathrm{~mm}$ at a single station and a 'single very heavy rainfall event' when the rainfall at a single station exceeds $115 \mathrm{~mm}$. This value is close to the $125 \mathrm{~mm}$ used by Bradley and Smith (1994) and the $130 \mathrm{~mm}$ used by Chen et al. (2007).

Two additional heavy rainfall classes are defined which combined the areal average rainfall and rainfall at individual rainfall stations. A 'major rain event' is defined when the average daily rainfall over Gauteng exceeds $10 \mathrm{~mm}$ with at least $50 \mathrm{~mm}$ at a single station and an 'extreme rain event' is defined when the average Gauteng rainfall exceeds $15 \mathrm{~mm}$ with more than $75 \mathrm{~mm}$ at a single station.

\section{Seasonal rainfall characteristics over Gauteng}

The average Gauteng monthly rainfall was calculated for each summer month from 1978 to 2008 . The monthly values were

\section{Table 1}

The early summer (October to December) and late summer (January to March) average rainfall totals $(\mathrm{mm})$ for 1977 to 2009. The grey cells show rainfall more than $400 \mathrm{~mm}$, while the black cells show rainfall less than $200 \mathrm{~mm}$.

\begin{tabular}{|c|c|c|c|}
\hline & \multicolumn{3}{|c|}{ Area-Average Rainfall Totals (mm) } \\
\hline & $\begin{array}{c}\text { Early Summer } \\
\text { (Oct-Dec) }\end{array}$ & $\begin{array}{l}\text { Late Summer } \\
\text { (Jan-Mar) }\end{array}$ & Total \\
\hline $77 / 78$ & 264 & 515 & 779 \\
\hline $78 / 79$ & 159 & 182 & 341 \\
\hline $79 / 80$ & 350 & 374 & 724 \\
\hline $80 / 81$ & 258 & 333 & 591 \\
\hline $81 / 82$ & 221 & 268 & 489 \\
\hline $82 / 83$ & 214 & 186 & 400 \\
\hline $83 / 84$ & 378 & 186 & 564 \\
\hline $84 / 85$ & 248 & 283 & 531 \\
\hline $85 / 86$ & 294 & 194 & 488 \\
\hline $86 / 87$ & 412 & 348 & 760 \\
\hline $87 / 88$ & 324 & 274 & 598 \\
\hline $88 / 89$ & 238 & 338 & 576 \\
\hline $89 / 90$ & 324 & 254 & 578 \\
\hline $90 / 91$ & 191 & 441 & 632 \\
\hline $91 / 92$ & 223 & 164 & 387 \\
\hline $92 / 93$ & 285 & 272 & 557 \\
\hline $93 / 94$ & 406 & 348 & 754 \\
\hline $94 / 95$ & 277 & 292 & 569 \\
\hline $95 / 96$ & 452 & 516 & 968 \\
\hline 96/97 & 291 & 464 & 755 \\
\hline $97 / 98$ & 258 & 268 & 526 \\
\hline 98/99 & 367 & 184 & 551 \\
\hline $99 / 00$ & 225 & 568 & 793 \\
\hline $00 / 01$ & 340 & 214 & 554 \\
\hline $01 / 02$ & 332 & 193 & 525 \\
\hline $02 / 03$ & 188 & 253 & 441 \\
\hline $03 / 04$ & 175 & 388 & 563 \\
\hline $04 / 05$ & 204 & 267 & 471 \\
\hline $05 / 06$ & 171 & 452 & 623 \\
\hline $06 / 07$ & 254 & 110 & 364 \\
\hline $07 / 08$ & 299 & 409 & 708 \\
\hline $08 / 09$ & 267 & 363 & 630 \\
\hline Average & 278 & 309 & 587 \\
\hline
\end{tabular}

used to calculate an average rainfall value for early summer (October to December) and late summer (January to March) as depicted in Table 1. The average summer rainfall (October to March) over Gauteng for this 32-yr period was $587 \mathrm{~mm}$. The highest summer rainfall occurred during the 1995/96 season with $968 \mathrm{~mm}$ followed by the summer of 1999/2000 with $793 \mathrm{~mm}$. The driest summer was 1978/79 when the average Gauteng rainfall was $341 \mathrm{~mm}$. The second-driest summer was in 2006/07 when the average rainfall was $364 \mathrm{~mm}$.

The totals depicted in Table 1 were standardised with respect to the long-term average and standard deviation for early and late summer rainfall and the results are depicted in Fig. 2. The 32-yr average early summer rainfall was $278 \mathrm{~mm}$ and late summer rainfall $309 \mathrm{~mm}$. The early summer with the highest average rainfall was in 1995 when $452 \mathrm{~mm}$ occurred over Gauteng. There were only 2 other years when the early 


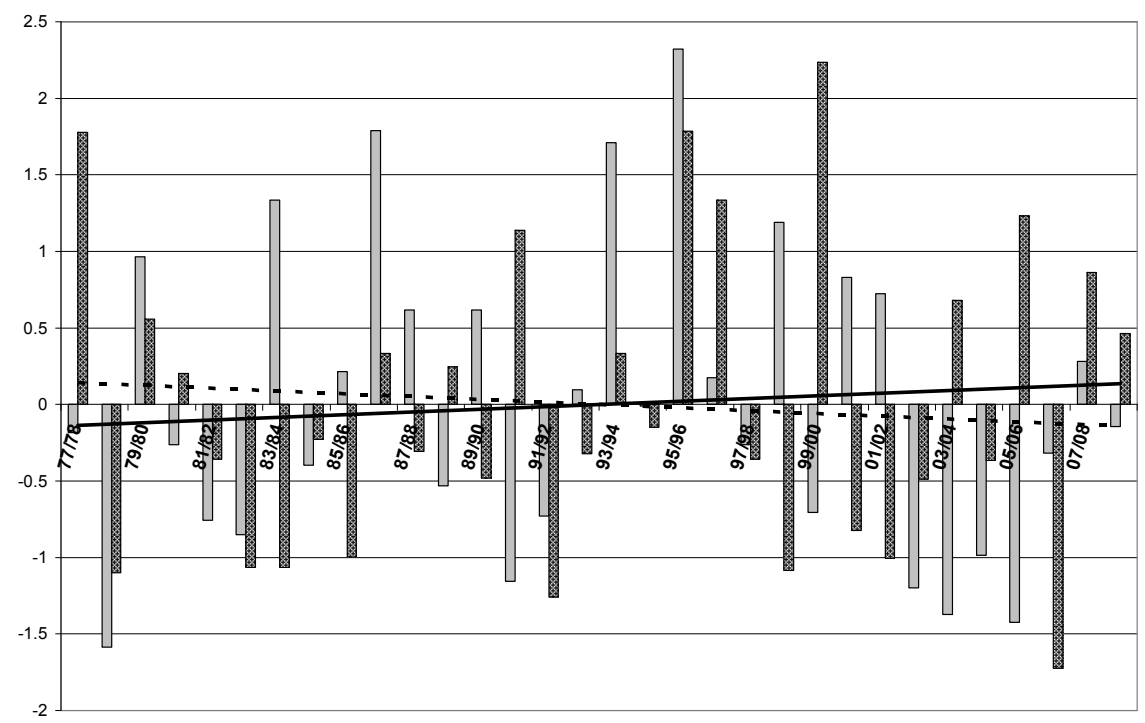

Figure 2

Standardised rainfall index for early summer (light grey) and late summer (dark grey) for 1977 to 2009. The early summer trend line is shown in a dotted line while the solid line is the late summer trend line.

summer rainfall exceeded $400 \mathrm{~mm}$ - $1986(412 \mathrm{~mm})$ and 1993 $(406 \mathrm{~mm})$. The early summer rainfall was less than $200 \mathrm{~mm}$ on 5 occasions in the past 32 years. Three of these very dry early summers occurred in the past decade (2002, 2003 and 2005). Also note from Fig. 2 the 5 consecutive years of below-normal early summer rainfall (2002 to 2006). This had not transpired before during this 32 -yr period, although the early 80 s had 3 consecutive dry years.

It is no surprise to find that the wettest late summer over Gauteng was in 2000, with $568 \mathrm{~mm}$ of rain, as tropical cyclone Eline invaded southern Africa in February 2000 (Dyson and Van Heerden, 2001) and was responsible for widespread heavy rainfall over the entire sub-continent, including Gauteng. Other particularly wet late summers were 1978, 1991, 1996, 1997, 2006 and 2008, with more than $400 \mathrm{~mm}$ of rain. The driest late summer in this $32-\mathrm{yr}$ period was in 2007 when a meagre $110 \mathrm{~mm}$ occurred. This value is lower than in $1992(164 \mathrm{~mm})$ and $1983(186 \mathrm{~mm})$. The latter 2 years have been identified as the years when the strongest droughts occurred over the summer rainfall area of South Africa (Rouault and Richard, 2003) since the 1921 drought. Although Fig. 2 depicts only Gauteng rainfall, it may be noted that a contributing factor to the severity of the drought during these 2 years was that the dry late summers were preceded by dry early summers. Indeed, from considering Fig. 2 it seems that notably low average early and late summer rainfall occurs rather seldom in 1 rainfall season. The correlation coefficient between early and late summer rainfall is only 0.027 indicating that there is no significant correlation between early and late summer rainfall over Gauteng. The appreciably dry early and late summers of 1978/79, 1982/83 and 1991/92 are therefore quite noteworthy. An equally rare event is a very wet early summer followed by a very wet late summer, which only happened in 1979/80 and 1995/96.

The very high rainfall totals over Gauteng in early 2000 $(568 \mathrm{~mm})$ were preceded by a dry early summer rainfall season when only $225 \mathrm{~mm}$ occurred. On 4 occasions a noteworthy wet ( 0.5 on the ordinate on Fig. 2) early summer was followed by a very dry late summer (1983/84, 1998/99, 2000/01 and 2001/02). It also happened at least 4 times that very dry early summers were followed by very wet late summers.

The dashed line on Fig. 2 is the trend line for early summer rainfall and the solid line the trend line for late summer rainfall. These trend lines indicate a decrease in the early summer rainfall while an increase is observed in the late summer rainfall over Gauteng. Trend analysis was done using the nonparametric Mann-Kendall test (Hcigizoglu et al., 2005). The downward trend in early summer rainfall has a confidence level of only $62 \%$ while the confidence level of the upward trend in late summer is $82 \%$. Therefore the trends observed on Fig. 2 are considered to be statistically not significant. However, further statistical trend analyses of the rainfall over Gauteng is recommended as recent work by Engelbrecht et al. (2009) found that the model-projected climate change shows an increase in summer rainfall over north-eastern South Africa.

\section{Monthly and daily rainfall characteristics over Gauteng}

\section{January months}

January months received the highest average monthly and daily rainfall over Gauteng. They also have the secondhighest number of days with rain. The standard deviation of the monthly average rainfall was the highest in January and February months indicating the high variability in the monthly average rainfall during these 2 months. This is reflected in the values in Table 2 indicating that the average January rainfall is $126 \mathrm{~mm}$ but the minimum monthly average rainfall was only $56 \mathrm{~mm}$ in 2001. In contrast, in 1978 rainfall of $324 \mathrm{~mm}$ was recorded; this is the highest monthly rainfall for any month during this 32 -yr period. In the same month the monthly averaged daily rainfall was $10.5 \mathrm{~mm}$, more than double the average for all January months $(4.1 \mathrm{~mm})$. On average rainfall occurs quite often during January months as more than $0 \mathrm{~mm}$ of rain was recorded on $23 \mathrm{~d}$. In 2005 there were $28 \mathrm{~d}$ with some rain and in 2001 and 2007 only $14 \mathrm{~d}$ with rain

\section{December months}

December months have the second-highest monthly average rainfall $(109 \mathrm{~mm})$ and they have the most days with some rain (24 d). The December months of 1988 and 1991 had $29 \mathrm{~d}$ on which some rainfall occurred. The standard deviation of the average monthly December rainfall is $30 \mathrm{~mm}$. This value is about half of the standard deviation in January and February months. 


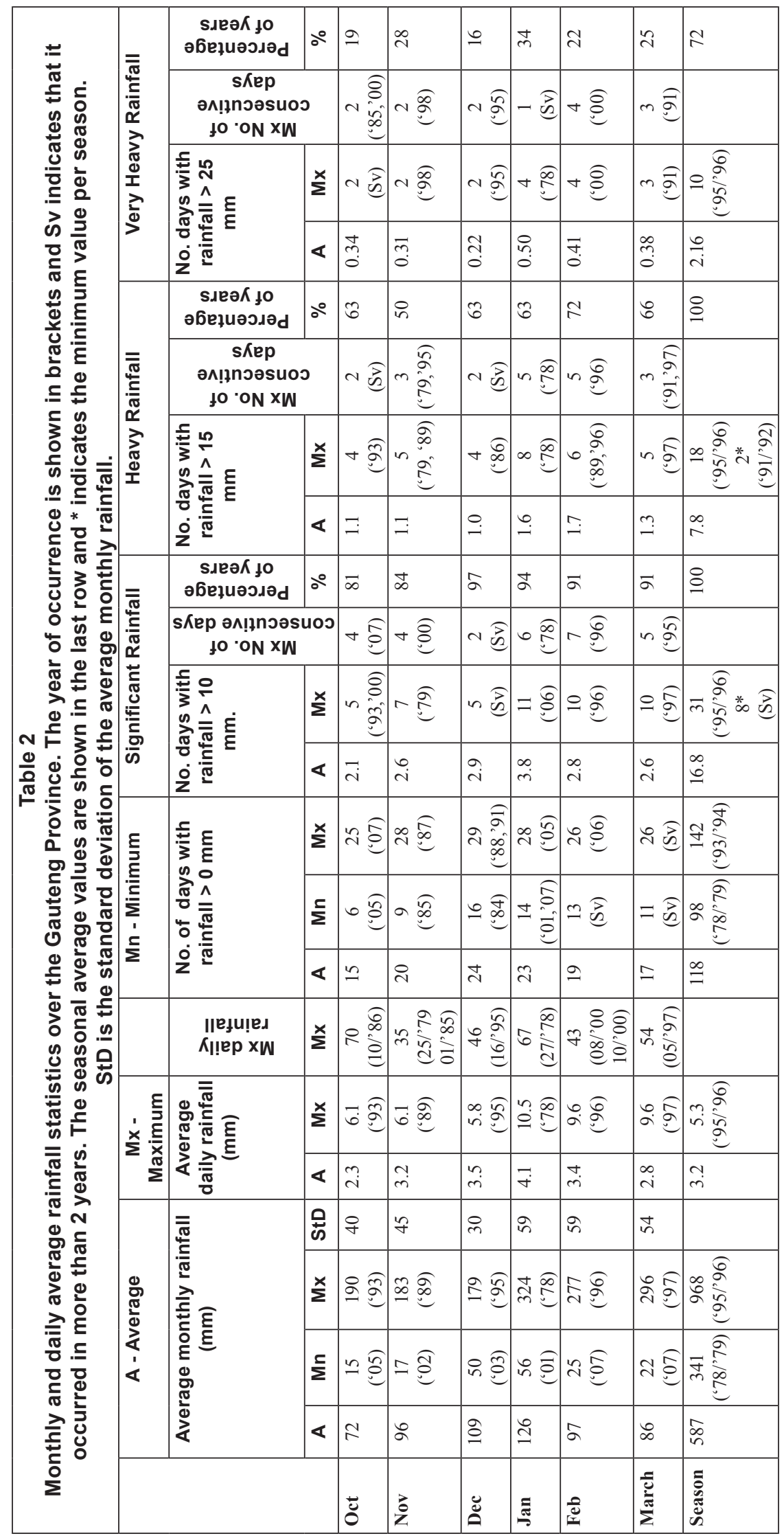

February and November months

The average monthly rainfall for November months $(96 \mathrm{~mm})$ and February months $(97 \mathrm{~mm})$ is very similar as is the number of days with more than $0 \mathrm{~mm}$ of rain at approximately $20 \mathrm{~d}$. However, the standard deviation in November was $45 \mathrm{~mm}$ while it is $59 \mathrm{~mm}$ in February. The minimum average monthly rainfall in a November month was $17 \mathrm{~mm}$ (2002) with a maximum of $183 \mathrm{~mm}$ in 1989. The minimum average monthly rainfall value in February months $(25 \mathrm{~mm})$ is similar to November months but the maximum monthly rainfall was significantly higher at $277 \mathrm{~mm}$.

\section{March and October months}

The average monthly rainfall during March $(86 \mathrm{~mm}$ ) was higher than in October $(72 \mathrm{~mm})$ even though the number of days with some rain was very similar (15 to $17 \mathrm{~d}$ ). The standard deviation of the average monthly rainfall in March was $54 \mathrm{~mm}$ and $40 \mathrm{~mm}$ in October. The maximum monthly average rainfall in a March month was approximately $100 \mathrm{~mm}$ more in March $(296 \mathrm{~mm})$ than in October $(190 \mathrm{~mm})$.

It is also interesting to note from Table 2 that the month with the most rain days did not necessarily coincide with the month with the highest rainfall. For example, the highest rainfall in a December month was in 1995 but this month had only $23 \mathrm{~d}$ with rain, very close to the monthly average. Some rainfall occurs on average on $118 \mathrm{~d}$ in the summer season, which is $64 \%$ of all days in summer. The 2006/07 rainfall season was particularly dry as it had only $98 \mathrm{~d}$ with rain. The 1993/94 season had $142 \mathrm{~d}$ with some rain; this is close to $80 \%$ of the summer days.

A South African weather forecaster should be aware of the increase in the average monthly rainfall during the progression of the summer from October to January with a decrease in February and March. On average October will receive some rainfall on about $50 \%$ of the days while in December and January more than $70 \%$ of the days receive some rainfall on average. By March the number of rain days has decreased to about $50 \%$. Weather forecasters should also take cognisance of the fact that even though the average monthly rainfall in January is higher than in December months, December has slightly more 
days with rain with a lower variability in the monthly average rainfall. The average monthly rainfall in late summer has high variability with maximum average monthly rainfall values all above $250 \mathrm{~mm}$.

\section{Synoptic circulation in wet and dry seasons}

The average 850 and 500hpa geopotential heights for the wettest and driest early and late summer seasons are displayed in Fig. 3. The average early summer rainfall of 1995 was $452 \mathrm{~mm}$ and there were $5 \mathrm{~d}$ when the area-average rainfall was more than 25 $\mathrm{mm}$, while there were $4 \mathrm{~d}$ when rainfall at a single station exceeded $115 \mathrm{~mm}$. At the $850 \mathrm{hPa}$ level a deep low pressure system (1 490 gpm) was located over northern Namibia, extending a trough to the south coast of South Africa (Fig. 3A). The Indian Ocean High $(\mathrm{IOH})$ was responsible for the inflow of warm moist air from over the Mozambique Channel into Gauteng. At the $500 \mathrm{hPa}$ level (Fig. 3C) the average early summer geopotential height field shows a weak trough west of South Africa and a high over northern Namibia/Botswana. The early summer of 1978 had only $159 \mathrm{~mm}$ of rain, there were no days which had area-average rainfall of more than $25 \mathrm{~mm}$ and only $2 \mathrm{~d}$ which had area-average rainfall of more than 15 $\mathrm{mm}$. There were $5 \mathrm{~d}$ where rainfall at a single station exceeded $50 \mathrm{~mm}$ (compared to the $20 \mathrm{~d}$ in 1995), and there was not a single day that had more than 115 $\mathrm{mm}$. At the $850 \mathrm{hPa}$ level the trough was established over the western interior of South Africa while the low pressure over Namibia was considerably weaker (1 510 $\mathrm{gpm})$ and located further
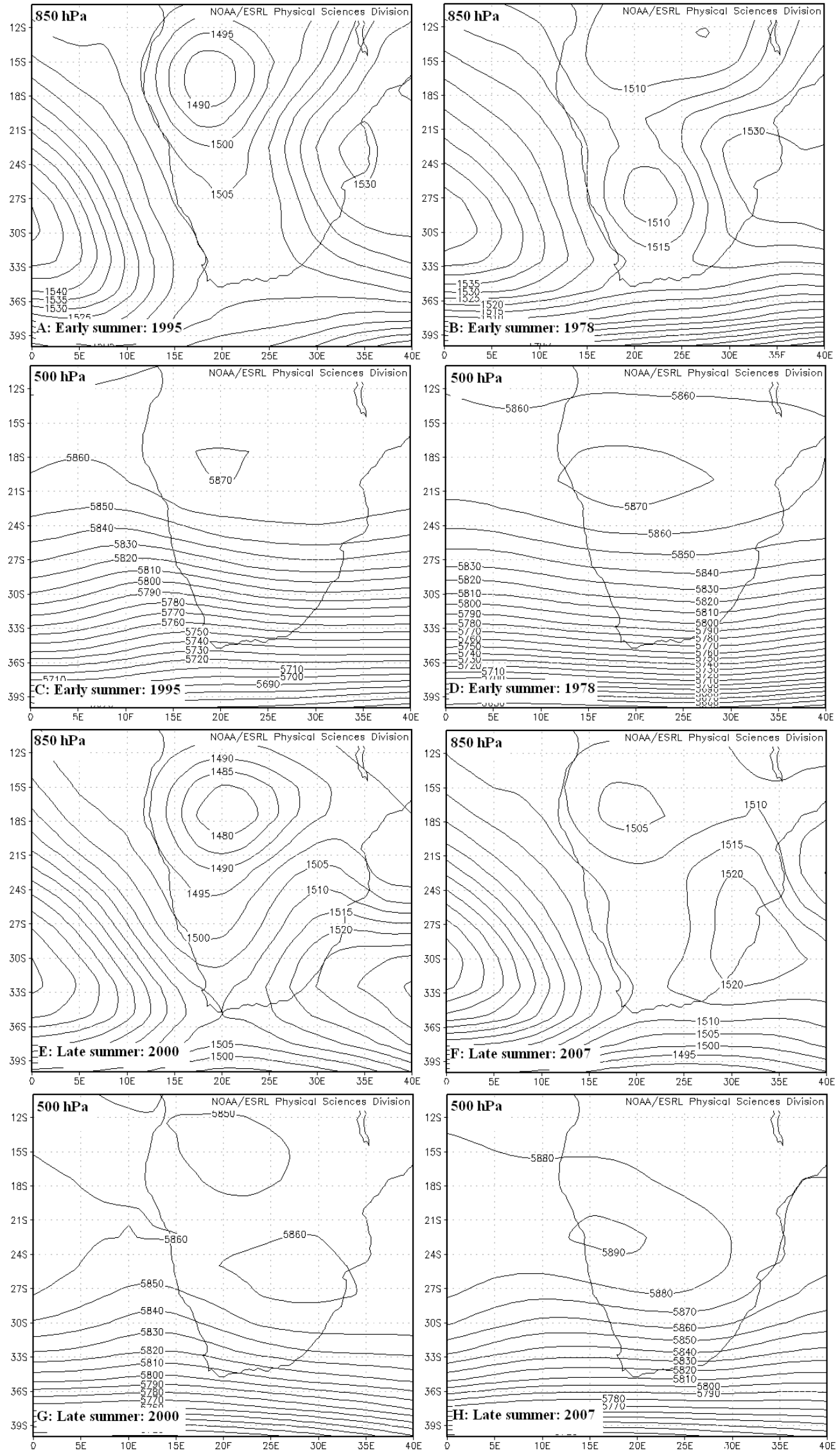

Figure 3

The average geopotential heights (in gpm) at 850 and $500 \mathrm{hPa}$ for the early summers of the 1995/96 and $1978 / 79$ seasons $(A-D)$ as well as for the late summers of the $1999 / 2000$ and the $2006 / 2007$ seasons $(E-H)$ 
west than in 1995 (Fig. 3B). The IOH extended over the eastern interior of the subcontinent. At the $500 \mathrm{hPa}$ level the trough which was present in 1995 was not present and the high pressure over northern Namibia was stronger than in 1995 (Fig. 3D)

In the late summer of 2000, $568 \mathrm{~mm}$ of rain occurred. There were $5 \mathrm{~d}$ when the area-average rainfall was more than $25 \mathrm{~mm}$ and there were $7 \mathrm{~d}$ when the rainfall at a single station exceeded $115 \mathrm{~mm}$. There are many similarities between the $850 \mathrm{hPa}$ geopotential height fields in the early summer of the $1995 / 96$ season and the late summer of the 1999/2000 season. In both instances the low over northern Namibia was dominant and the trough extended southwards over central and western South Africa. The IOH was located south-east of South Africa in 2000 allowing for a more direct inflow of moisture from the Mozambique Channel over South Africa (Fig. 3E). At the $500 \mathrm{hPa}$ level a trough was present west of South Africa extending northwards and dividing the high pressure over Namibia into 2 cells. The eastern cell was located far to the south-east over southern Botswana and northern South Africa. In 2007 only $110 \mathrm{~mm}$ of rain occurred on average over Gauteng. There were no days when the area-average rainfall exceeded $25 \mathrm{~mm}$, and $50 \mathrm{~mm}$ at a single station was exceeded only on $4 \mathrm{~d}$. In 2000 it happened on $46 \mathrm{~d}$. At the $850 \mathrm{hPa}$ level the high pressure was located over the eastern interior and although the low over Namibia was present (1 $505 \mathrm{gpm}$ ) it was considerably weaker than in 2000 (1 $480 \mathrm{gpm})$. A strong 500-hPa high (5 890 gpm) was present over Namibia (Fig. 3H).

\section{Daily area-averaged heavy rainfall characteristics over Gauteng}

The maximum area-averaged rainfall which occurred on any day over Gauteng during this period was $70 \mathrm{~mm}$ on 28 October 1986 (Table 2). The second-highest average daily rainfall occurred on 27 January $1978(67 \mathrm{~mm})$. The average daily rainfall exceeded $50 \mathrm{~mm}$ on only $5 \mathrm{~d}$ during this $32-\mathrm{yr}$ period. Two of these events occurred in January months and 2 in March months. On 28 October 1986 the weather system over South Africa was what Taljaard (1996) defined as a southward extending $\mathrm{V}$-shaped trough. There was a well-established low pressure system over Botswana at $850 \mathrm{hPa}$ advecting warm humid surface level air into Gauteng. At $500 \mathrm{hPa}$ a weak trough was present over the south-western parts of the country. All the other weather systems responsible for rainfall in excess of $50 \mathrm{~mm}$ over Gauteng were westerly troughs, cold cored in the upper troposphere, the only exception being that of 27 January 1978 when there was a continental low pressure system over Botswana (Dyson and Van Heerden, 2002).

\section{Daily area-averaged rainfall in January months}

Table 2 presents the average number of days per month on which the areal average rainfall exceeds the thresholds of the 3 different heavy rainfall classes ('significant rain event', 'heavy rain event' and 'very heavy rain event'). January months have the most 'significant' (3.8 d), 'heavy' (1.6 d) and 'very heavy' $(0.5 \mathrm{~d})$ rainfall days. Rainfall exceeding $10 \mathrm{~mm}$ occurred quite regularly during January as $94 \%$ of the years had at least 1 such an event. Heavy rainfall occurred in $63 \%$ of the Januaries (the same percentage of October and December months) and very heavy rainfall occurred in $34 \%$ of the Januaries. The average number of significant rainfall days per month may give the weather forecaster an idea of how likely such an event is in any particular month. It may also be instructive to provide information on how often these events occur on consecutive days in any month. January was the month with the highest number of multiple heavy rainfall days for all 3 heavy rainfall classes. There were 11 significant rainfall days in 2006, 8 heavy rainfall days and 4 very heavy rainfall days in 1978 . These values were not surpassed in any of the other summer months. Rainfall exceeding $25 \mathrm{~mm}$ was not observed in a January on $2 \mathrm{~d}$ in a row but in 1978 there were 5 consecutive days with 'heavy rainfall' and 6 with 'significant rainfall'.

\section{Daily area-averaged rainfall in February and March months}

The heavy rainfall characteristics in February and March are similar to January. Significant rainfall occurred on average on $2.8 \mathrm{~d}$ in February and $2.6 \mathrm{~d}$ in March. These events were quite frequent as $91 \%$ of the years had days with significant rainfall and multiple events had been regular in both months. February had the highest number of average heavy rainfall days $(1.7 \mathrm{~d})$ and these events occurred in $72 \%$ of the years. In February 1996 there were 5 consecutive days when the average rainfall exceeded $15 \mathrm{~mm}$. Very heavy rainfall occurred in approximately a quarter of February and March months.

\section{Daily area-averaged rainfall in December months}

December had the second-highest number of significant rainfall days $(2.9 \mathrm{~d})$ and these events occurred in $97 \%$ of the years However, December had the lowest average number of heavy rainfall ( $1 \mathrm{~d})$ and very heavy rainfall $(0.22 \mathrm{~d})$ days. Very heavy rainfall is rare in December months as it occurred in only $16 \%$ of the years.

\section{Daily area-averaged rainfall in October and March months}

The characteristics of heavy rainfall during October and November months are similar. Both months had on average just over $2 \mathrm{~d}$ per month with significant rainfall, $1.1 \mathrm{~d}$ with heavy rainfall and approximately $0.3 \mathrm{~d}$ with very heavy rainfall. Significant rainfall occurred in more than $80 \%$ of the years and both months had 4 consecutive days with these events. There were less multiple days with significant, heavy and very heavy rainfall per month than in late summer. Very heavy rainfall occurred in only $19 \%$ of October months and $28 \%$ of November months.

There are on average 16.8 significant rainfall days per season. This is more than $100 \mathrm{~d}$ less than the number of days when the average daily rain exceeds $0 \mathrm{~mm}$ (Table 2). There are on average 7.8 heavy rainfall days and 2.16 very heavy rainfall days. In the very wet 1995/96 season there were 31 significant rain days, 18 heavy rainfall days, and 10 very heavy rainfall days.

\section{Heavy rainfall at individual stations}

The highest 24-h rainfall which was recorded at any rainfall station during this 32-yr period was $300 \mathrm{~mm}$ which occurred on 18 December 2006 at Viljoensdrift, located in southern Gauteng (Fig. 1). On 18 December 2006 the atmospheric circulation over South Africa was dominated by a deep surface trough, extending to a low off the south-east coast. There was a strong inflow of surface moisture into the central interior from 
Botswana and Zambia. At $500 \mathrm{hPa}$ there was a high pressure system located over northern Namibia causing south-westerly winds over Gauteng. The second-highest 24-h rainfall at a single station, $280 \mathrm{~mm}$, occurred on 27 January 1978 at Rietondale in Pretoria. This was the same day which received the highest area-averaged rainfall and, as mentioned earlier, the weather system on this day was a continental tropical low pressure. There were a further $6 \mathrm{~d}$ when the maximum daily rainfall at any station exceeded $200 \mathrm{~mm}$. Two of these events happened in October months (29 October 1995 and 25 October 2001) and 1 in March (19 March 2003). On these days a cut-off low pressure system was present over South Africa. The other 3 events were all caused by westerly troughs. The monthly maximum rainfall was less than $200 \mathrm{~mm}$ only in February months as the highest rainfall recorded during a February was $142 \mathrm{~mm}$ in 1996.

The average and maximum number of days when rainfall at an individual station exceeds the 3 different heavy rainfall classes is depicted in Table 3 . The percentage of years in which these events occurred is also indicated on Table 3 as well as the maximum number of consecutive days of occurrence. The last row indicates the seasonal averages and extremes.

\section{Single station significant rainfall}

Rainfall exceeded $50 \mathrm{~mm}$ at a single station on nearly $28 \mathrm{~d}$ in a summer season. January months had the most days with single station significant rainfall events (7 d), followed by December and February with close to $5 \mathrm{~d}$. In January 2006 there were $17 \mathrm{~d}$ when daily rainfall exceeded $50 \mathrm{~mm}$ for at least 1 station, and in January 2008 there were 8 consecutive days with single station significant rainfall over Gauteng. This was surpassed only in February of 1996 when $50 \mathrm{~mm}$ was exceeded at a single station on 9 consecutive days. The season with the highest number of single station significant rainfall days was the 1999/2000 summer season which had $56 \mathrm{~d}, 46$ of these days occurring in late summer. The lowest seasonal total of significant single station rainfall was in 1985/86 with only 7 of these days. Figure 2 shows that it was the late summer of the $1985 / 86$ season that was particularly dry but during this time there were at least $3 \mathrm{~d}$ when rainfall exceeded $50 \mathrm{~mm}$ at a single station. Even the extremely dry 1982/83 and 1991/92 had 11 and 15 of these events respectively. Significant rainfall at single stations occurs frequently, even during years which are considered to be dry. All January months had some days with these events and it occurred in $78 \%$ of October months.

\section{Single station heavy rainfall}

Rainfall exceeding $75 \mathrm{~mm}$ at a single station (single station heavy rainfall) occurred infrequently, with the average monthly occurrences being less than $2 \mathrm{~d}$ for all summer months, except for January (2.6 d). January months had at least 1 such event in $88 \%$ of the years, while in December these events occurred in about half of the years (53\%). February 2000 and March 1997 had a maximum of 10 of these days in a single month. During February 1996, there were 6 consecutive days

\begin{tabular}{|c|c|c|c|c|c|c|c|c|c|c|}
\hline \multirow{6}{*}{\multicolumn{2}{|c|}{ 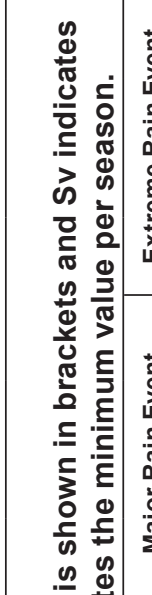 }} & 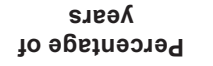 & $\circ$ & $\stackrel{\infty}{\sim}$ & $\approx$ & $\stackrel{2}{\sim}$ & in & in & Ұ & $\infty$ \\
\hline & & \multirow{2}{*}{ 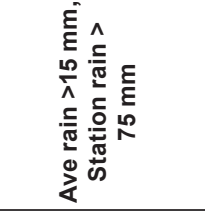 } & $\left.\right|^{x}$ & $\underset{n}{\frac{a}{n}}$ & $\begin{array}{l}\tilde{\sigma} \\
\hat{a} \\
\infty \\
0\end{array}$ & $\underbrace{0}_{m}$ & $\underbrace{\infty}_{n}$ & $\begin{array}{l}0 \\
0 \\
\vdots \\
0 \\
0 \\
0\end{array}$ & $\underbrace{\hat{a}}_{n}$ & $=\frac{0}{2}$ \\
\hline & & & $\varangle$ & $\stackrel{+}{0}$ & $\stackrel{+}{0}$ & $\stackrel{+}{0}$ & $\stackrel{\circ}{i}$ & $\exists$ & $\stackrel{\infty}{\circ}$ & 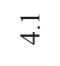 \\
\hline & & $\begin{array}{c}\text { s.еәк } \\
\text { to әбеұиәэдәd }\end{array}$ & $\therefore$ & $\hat{6}$ & $\hat{6}$ & ఫ & ఫ & $\stackrel{\infty}{\sim}$ & $\vec{\infty}$ & $@$ \\
\hline & & \multirow{2}{*}{ 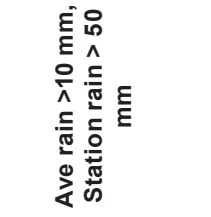 } & ||$^{x}$ & $\begin{array}{l}\hat{\partial} \\
\text { jं } \\
\vdots \\
n\end{array}$ & \begin{tabular}{l}
2 \\
$\infty$ \\
2 \\
\multirow{2}{5}{} \\
$n$
\end{tabular} & $\underbrace{0}_{n}$ & $\begin{array}{l}0 \\
\stackrel{0}{0} \\
=\end{array}$ & $\underbrace{0}_{a}$ & $\underset{\infty}{\hat{a}}$ & 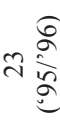 \\
\hline & & & $\varangle$ & $\stackrel{?}{-}$ & $\stackrel{n}{-}$ & $\stackrel{\infty}{-}$ & $\vec{m}$ & $\stackrel{m}{i}$ & $\vec{i}$ & $\vec{\beth}$ \\
\hline \multirow{4}{*}{\multicolumn{2}{|c|}{ 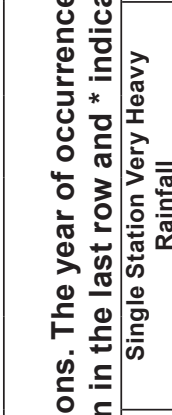 }} & \multicolumn{2}{|l|}{ 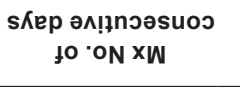 } & 氙 & 占 & 氙 & 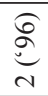 & $\underbrace{\stackrel{\Xi}{8}}_{m}$ & 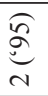 & \\
\hline & & $\begin{array}{c}\text { sдеәК } \\
\text { to әбеłиәэдәd }\end{array}$ & $\circ$ & 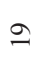 & 0 & $\tilde{N}$ & $\underset{n}{\infty}$ & 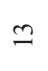 & $\approx$ & 8 \\
\hline & & 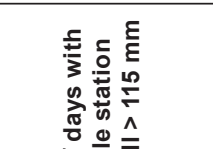 & ||$^{x}$ & $\underbrace{\stackrel{8}{8}}_{m}$ & $\underbrace{\frac{\sigma}{a}}_{\sim}$ & $\underbrace{0}_{\sim}$ & $\stackrel{8}{\circ}$ & $\underset{\text { }}{\stackrel{8}{2}}$ & $\underset{\forall}{\hat{a}}$ & $\begin{array}{l}0 \\
2 \\
\vdots \\
2 \\
a \\
a\end{array}$ \\
\hline & & 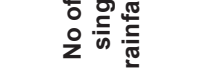 & $\varangle$ & ֻै & $\stackrel{8}{0}$ & $\stackrel{2}{2}$ & ถุ & $\stackrel{\infty}{\stackrel{0}{0}}$ & $\stackrel{\infty}{n}$ & 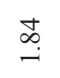 \\
\hline 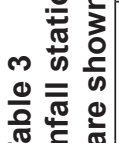 & \multirow{4}{*}{ 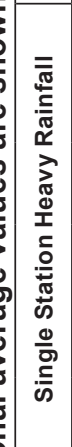 } & \multicolumn{2}{|l|}{$\begin{array}{c}\text { sКep әк!̣noәsuoo } \\
\text { 10 '0N XW }\end{array}$} & 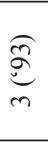 & $\begin{array}{l}5 \\
2 \\
0 \\
\infty \\
0 \\
0\end{array}$ & 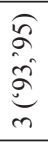 & $\underbrace{2}_{n}$ & $\underbrace{0}_{0}$ & $\underbrace{\widehat{a}}_{n}$ & \\
\hline \multirow{3}{*}{ 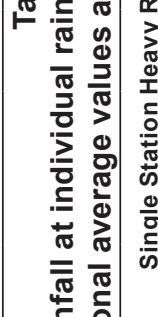 } & & 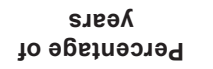 & $0^{\circ}$ & f & 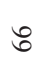 & $\tilde{n}$ & $\infty$ & 8 & $\widehat{6}$ & $\hat{a}$ \\
\hline & & 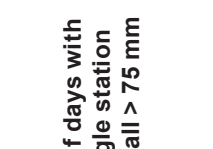 & ||$^{x}$ & $\underbrace{\stackrel{8}{8}}_{0}$ & $\underbrace{\frac{\sigma}{\sigma}}_{\sigma}$ & 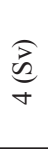 & $\begin{array}{l}0 \\
8 \\
8 \\
0 \\
0\end{array}$ & @̊ & $\begin{array}{l}\hat{\widehat{O}} \\
\hat{0}\end{array}$ & 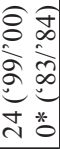 \\
\hline & & $2 \cdot \frac{5}{2} \cdot \frac{5}{\pi}$ & $\varangle$ & $\ddot{\circ}$ & $\exists$ & $\stackrel{m}{-}$ & $\stackrel{o}{i}$ & 9 & 今 & $\dddot{n}$ \\
\hline 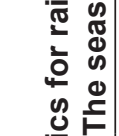 & \multirow{4}{*}{ 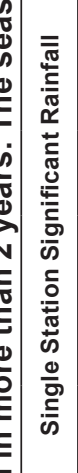 } & \multicolumn{2}{|l|}{ 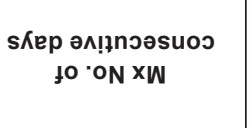 } & $\underbrace{\stackrel{0}{8}}_{n}$ & $\begin{array}{l}\hat{\sigma} \\
\vdots \\
a \\
n \\
n\end{array}$ & $\underbrace{8}_{n}$ & $\underbrace{\infty}_{\infty}$ & $\underbrace{2}_{a}$ & $\underbrace{8}_{0}$ & \\
\hline \multirow{5}{*}{ 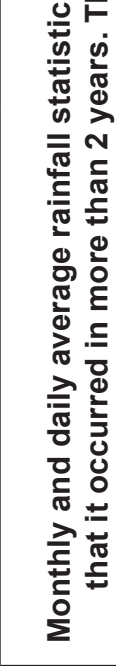 } & & $\begin{array}{c}\text { sıеәК } \\
\text { to әбеұиәэләd }\end{array}$ & $\circ$ & $\stackrel{\infty}{\curvearrowright}$ & $\infty$ & $\hat{a}$ & $@$ & $\hat{a}$ & J & $\cong$ \\
\hline & & 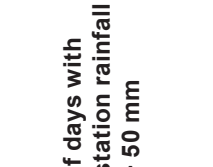 & $\mid \mathbf{x}^{\mathbf{x}}$ & 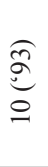 & $\underbrace{\widehat{\sigma}}_{0}$ & $\begin{array}{l}0 \\
\vdots \\
0 \\
0 \\
0\end{array}$ & 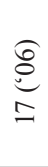 & 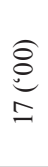 & $\underset{n}{\stackrel{8}{0}}$ & 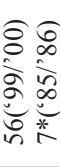 \\
\hline & & $2 \frac{0}{\frac{5}{\omega}}$ & $\varangle$ & $\stackrel{m}{i}$ & $\stackrel{n}{n}$ & $\vec{n}$ & $\stackrel{\circ}{r}$ & $\vec{n}$ & $\stackrel{\bullet}{+}$ & $\stackrel{\vec{\sim}}{\stackrel{\sim}{*}}$ \\
\hline & & $\begin{array}{l}\text { ॥ерu!!ed uo!!ełs } \\
\text { әббu!s К‼ep xW }\end{array}$ & $\left.\right|^{x}$ & 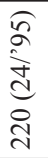 & 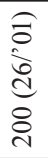 & $\begin{array}{l}0 \\
0 \\
\infty \\
\stackrel{\infty}{0} \\
0 \\
0\end{array}$ & 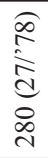 & 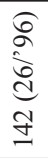 & 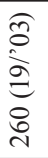 & \\
\hline & & & & $\overline{0}$ & zi & อ̆ & $\stackrel{\bar{\pi}}{\Xi}$ & $\overline{0}$ & 离 & 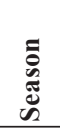 \\
\hline
\end{tabular}




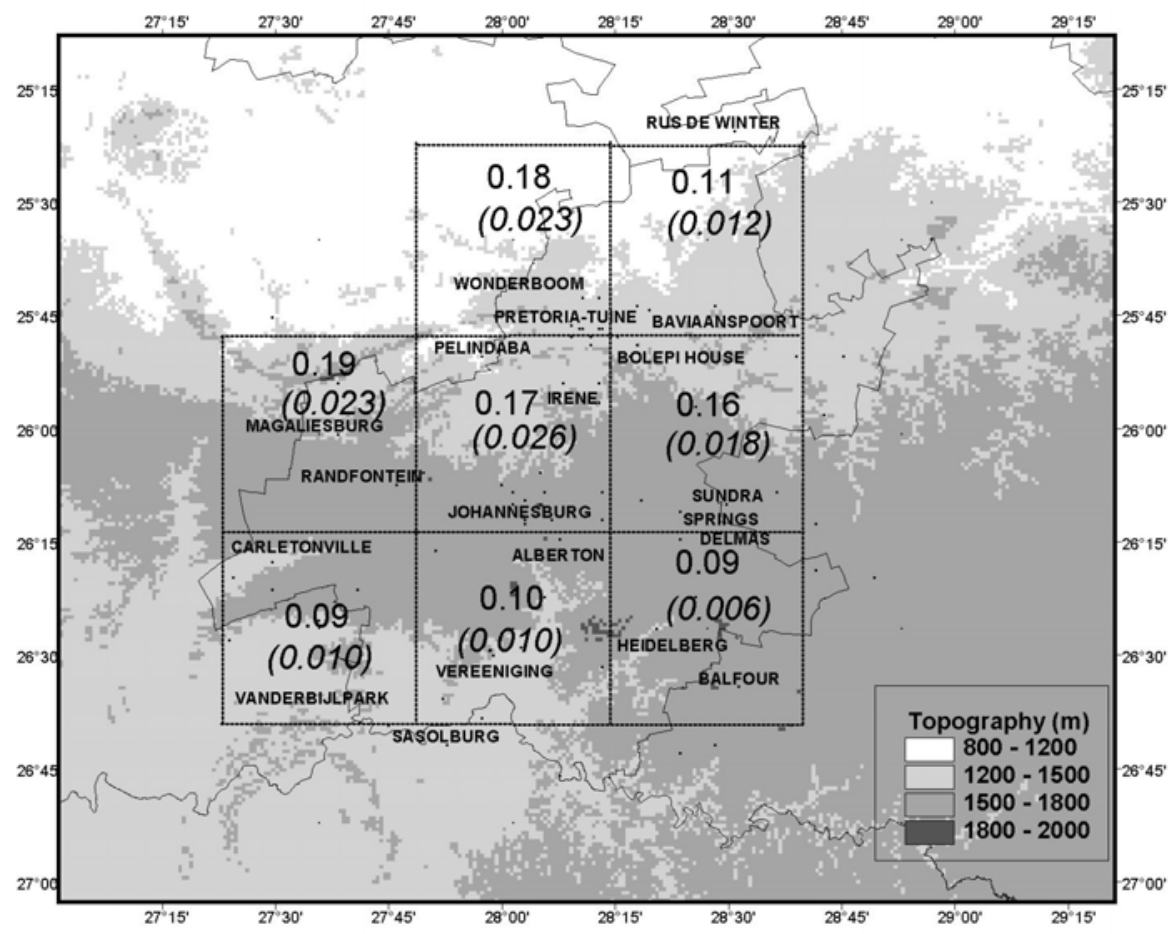

Figure 4

The location of eight $0.5^{\circ}$ by $0.5^{\circ}$ grid boxes over Gauteng. The values show the total number of rainfall stations which received more than $75 \mathrm{~mm}$ and $115 \mathrm{~mm}$ (in brackets) in each grid box. The values are standardised to 100 stations per grid box. The shading indicates height (in $\mathrm{m}$ ) a. m. s. I.

when the rainfall exceeded $75 \mathrm{~mm}$. Single station heavy rainfall events occur on nearly $10 \mathrm{~d}$ a season. There were 24 of these days during the 1999/2000 summer and not a single day during the 1983/84 season. Figure 2 shows that the average early summer rainfall of the 1983/84 season was above normal, as $377 \mathrm{~mm}$ was recorded over Gauteng from October to December. There were $69 \mathrm{~d}$ with rain during these 3 months; however, on none of these days did the rainfall at a single station exceed $75 \mathrm{~mm}$

\section{Single station very heavy rainfall}

Single station rainfall exceeding $115 \mathrm{~mm}$ is very rare over Gauteng. During the 32-yr period, rainfall at any station exceeded $115 \mathrm{~mm}$ on only $59 \mathrm{~d}$. On average these events occur on less than $1 \mathrm{~d}$ in each of the summer months. January months have the highest average value $(0.59 \mathrm{~d})$ but only $38 \%$ of the years recorded at least 1 of these events. There were only $19 \mathrm{~d}$ in all the January months where rainfall at a single station exceeded $115 \mathrm{~mm}$. Rainfall at a single station exceeded $115 \mathrm{~mm}$ on $3 \mathrm{~d}$ during October 2000 . However, these events were rare in October as it occurred in only $19 \%$ of the years. The events were most infrequent in November months as only $6 \%$ of the years received some of these events. There were only 2 Novembers, 1995 and 2001, which had days with very heavy rainfall at a single station. Bearing in mind the areal average rainfall as depicted in Table 2, February had the second-highest number of very heavy rainfall days. However, Table 3 shows that very heavy rainfall at a single rainfall station during February months is very rare, as only $13 \%$ of the years had days when the rainfall at a single station exceeded $115 \mathrm{~mm}$. Considering that there were only $59 \mathrm{~d}$ during this $32-\mathrm{yr}$ period which had rainfall of more than $115 \mathrm{~mm}$ at a single station, the unique rainfall character of the 1995/96 rainfall season is again emphasised (Table 3), as there were 10 'single station very heavy rainfall' days during this 1 season alone $-5 \mathrm{~d}$ in early summer and $5 \mathrm{~d}$ in late summer.

\section{Location of heavy rainfall at individual stations}

The number of stations which recorded more than $75 \mathrm{~mm}$ and more than $115 \mathrm{~mm}$ were calculated for the 8 grid boxes over Gauteng for the entire period. These results are depicted in Fig. 4 and are expressed as the total number of events per 100 stations. Single station significant and heavy rainfall events occur most frequently over the central and north-western parts of Gauteng. The main watershed in the Witwatersrand which divides the province into 2 major catchments, the Crocodile catchment to the north and the Vaal catchment to the south, lies between $26^{\circ} \mathrm{S}$ and $26^{\circ} 15^{\prime} \mathrm{S}$. The 3 grid boxes located south of this watershed receive only half the number of single station heavy and very heavy rainfall events when compared with those grid boxes further to the north. Consider Fig. 3 and the average $850 \mathrm{hPa}$ geopotential height fields in the very wet early summer of the 1995/96 season (Fig. 3A) and in the late summer of the 1999/2000 season (Fig. 3E). These maps illustrate that during seasons which receive a high number of heavy and very heavy rainfall days there is a deep surface low pressure system over northern Namibia and an IOH located east or south-east of South Africa. This high pressure causes an inflow of warm moist tropical air from the Mozambique Channel, which curves around the high pressure system and enters Gauteng from the north. The moisture-laden air is then forced to rise against the Witwatersrand resulting in a higher number of heavy rainfall events at the stations north of the watershed than further to the south.

\section{Major and extreme rain events}

The last 2 columns of Table 3 depict the results for the major (rainfall at a single station exceeded $50 \mathrm{~mm}$ and the average rainfall exceeded $10 \mathrm{~mm}$ ) and extreme (rainfall at a single station exceeding $75 \mathrm{~mm}$ and the average rainfall exceeding $15 \mathrm{~mm}$ ) rain events. On average January months have 3.1 major rain events per year followed by February which has 2.3 events. October months have the lowest number of events at 1.3 events. 
There is an average of 12.1 of these events per summer season. The maximum number of days with major rain events occurred in 1995/96 which had 23 such events. The maximum number of these events occurred in January 2006 with 11 d, followed by $9 \mathrm{~d}$ in February 1996. Major rain events occur relatively frequently as $84 \%$ of all December and January months had at least 1 of these events compared to only $63 \%$ of October and November months. Extreme rain events occur much less frequently. Fifty-six percent of January months received extreme rain events, followed by $50 \%$ of February months and $44 \%$ of March months. January and February on average both have approximately $1 \mathrm{~d}$ with major rain events and all the early summer months $0.4 \mathrm{~d}$. The late summer months all had a maximum of 5 of these events.

\section{Discussion}

January months have the highest average monthly rainfall; January had, on average, $23 \mathrm{~d}$ with rain and January also had the most significant, heavy and very heavy rainfall days. Approximately $20 \%$ of all significant, heavy and very heavy rainfall events occurred in January months. Every single January of this 32-yr period had at least $1 \mathrm{~d}$ with rainfall of more than $50 \mathrm{~mm}$ and there were in total $19 \mathrm{~d}$ in January where the rainfall at an individual station exceeded $115 \mathrm{~mm}$. This is a third of the total number of these events.

December had the second-highest average monthly rainfall and on average receives $24 \mathrm{~d}$ with some rain. December had approximately $3 \mathrm{~d}$ per year when the average Gauteng rainfall exceeded $10 \mathrm{~mm}$. However December had the lowest number of heavy and very heavy rainfall days. The highest 24-h rainfall at any station $(300 \mathrm{~mm})$ did occur in a December month but, considering the rainfall at individual rainfall stations, $115 \mathrm{~mm}$ was exceeded on only $7 \mathrm{~d}$ during December months and this occurred in about $20 \%$ of all the years.

The average monthly rainfall in February was lower than in December and it had, on average, only $19 \mathrm{~d}$ with rain. The average monthly rainfall during February months had a greater variance than in December months, as depicted by the standard deviation in Table 2. There were fewer days with some rain than in December but more heavy and very heavy rainfall days. However extreme rainfall at an individual station was rare in February. There were only $6 \mathrm{~d}$ when the rainfall exceeded $115 \mathrm{~mm}$. This seems to suggest that heavy and very heavy rainfall events during February months are associated with widespread rainfall over the entire province rather than copious rainfall at a single station.

October and March months may be considered the transition months as summer starts in October and ends in March. On average March receives more rainfall than October and also had slightly more days with rain. Heavy rainfall events occur on average approximately on $1 \mathrm{~d}$ per month in both months and very heavy rainfall on about $0.35 \mathrm{~d}$ per month. The highest average daily rainfall was recorded in an October month at $69 \mathrm{~mm}$. There were on average more days with rainfall in excess of 50 and $75 \mathrm{~mm}$ at a single station in March than in October.

Heavy and very heavy rainfall events occur more frequently in late summer, when $60 \%$ of these events were recorded. The same distribution is also present in the rainfall at individual stations. Sixty percent of days with more than $50 \mathrm{~mm}$ at a station, $65 \%$ of the days with more than 75 $\mathrm{mm}$, and $63 \%$ of those days with more than $115 \mathrm{~mm}$ occur in late summer. Rainfall stations located over the central and north-western part of Gauteng receive rainfall in excess of 75 and $115 \mathrm{~mm}$ more frequently than those in the south and southeast. On 7 of the 8 days when rainfall at a station surpassed 200 $\mathrm{mm}$ the atmospheric circulation was dominated by cold upper tropospheric temperatures and troughs or lows in the westerly circulation. On the remaining day a continental tropical low was situated over Botswana.

Whenever the rainfall over Gauteng exceeds $0 \mathrm{~mm}$, the percentage of rainfall stations reporting some rainfall is $40 \%$ on average. For significant, heavy and very heavy rainfall events the percentage of rainfall stations reporting more than $0 \mathrm{~mm}$ exceeds $80 \%$. These events happen when most of Gauteng receives some rainfall and may be classed as widespread heavy rainfall events. However, when the rainfall at an individual rainfall station exceeds $50 \mathrm{~mm}$ (the criteria used by the forecasters to issue warnings of heavy rainfall) the average percentage of rainfall stations reporting some rainfall is approximately $50 \%$. Heavy rainfall at single stations is therefore an isolated event which does not necessarily occur on days when the entire province receives some rainfall.

\section{Acknowledgements}

The author would like to express her sincere appreciation to Colleen de Villiers from the South African Weather Service for the rainfall data. Francois Engelbrecht is acknowledged for his many useful suggestions to enhance this paper and Christien Engelbrecht for the interest shown and many fruitful discussions. The South African Water Research Commission Project No. K5/1333 deals with the early warning of heavy rainfall and its support is acknowledged. The author also acknowledges the 2 anonymous reviewers, whose comments helped to clarify and improve the manuscript.

\section{References}

BEAVON KSO (2004) Johannesburg: The Making and Shaping of the City. UNISA Press, Pretoria. $373 \mathrm{pp}$.

BRADLEY AA and SMITH JA (1994) The hydrometeorological environment of extreme rainstorms in the southern plains of the United States. J. Appl. Meteorol. 33 1418-1431.

BROOKS HE and STENSRUD DJ (2000) Climatology of heavy rain events in the United States from hourly precipitation observations. Mon. Weather Rev. 128 (4) 1194-1201.

CHEN GT and YU C (1988) Study of level jet and extremely heavy rainfall over northern Taiwan in the Mei-Yu season. Mon. Weather Rev. 116 884-891.

CHEN C, CHEN Y, LIU C, LIN P and CHEN W (2007) Statistics of heavy rainfall occurrences in Taiwan. Weather Forecasting 22 (5) 981-1002.

DE CONING E, FORBES GS and POOLMAN EP (1998) Heavy precipitation and flooding on 12-14 February 1996 over the summer rainfall regions of South Africa: Synoptic and isentropic analyses. Natl. Weather Dig. 22 25-36.

DYSON LL and VAN HEERDEN J (2001) The heavy rainfall and floods over the northeastern interior of South Africa during February 2000. S. Afr. J. Sci. 97 80-86.

DYSON LL and VAN HEERDEN J (2002) A model for the identification of tropical weather systems. Water SA 28 (3) 249-258.

DYSON LL, VAN HEERDEN J and MARX HG (2002) Short-Term Forecasting Techniques for Heavy Rainfall. WRC Report No. 1011/1/02. Water Research Commission, Pretoria, South Africa.

ENGELBRECHT FA, McGREGOR JL and ENGELBRECHT CJ (2009) Dynamics of the Conformal-Cubic Atmospheric Model projected climate-change signal over South Africa. Int. J. Climatol. 29 (7) $1013-1033$. 
FRAGOSO M and TILDES GOMES T (2008) Classification of daily abundant rainfall patterns and associated large-scale atmospheric circulation types in Southern Portugal. Int. J. Climatol. 28 (4) 537-544.

GAUTENG DEPARTMENT OF HOUSING (2006) Gauteng Housing Annual Report 2006. Gauteng Department of Housing, Marshalltown.

HCIGIZOGLU HK, BAYAZIT M and ÖNÖZ B (2005) Trends in the maximum, mean, and low flows of Turkish rivers. J. Hydrometeorol. 6 (3) 280-290.

HOUZE RA, SMULL BF and DODGE P (1990) Mesoscale organization of springtime rainstorms in Oklahoma. Mon. Weather Rev. 118 613-654.

KRUGER AC (2004) Climate of South Africa. Climate Regions. WS45. South African Weather Service, Pretoria, South Africa.

MADDOX RA, CHAPPELL CF and HOXIT LR (1979) Synoptic and meso- $\alpha$ scale aspects of flash flood events. Bull. Am. Meteorol. Soc. $60115-123$.

MARX HG, DYSON LL and VAN HEERDEN J (2003) Verification of rainfall forecasts for the Vaal Dam catchment for the summer rainfall seasons of 1994 to 1998. Water SA 29 (2) 195-200.

NGUBO N, MALALA R, MABUSELA X, DE CONING E, ROSENFELD D and KERKMANN J (2008) Hailstorm in Potchefstroom area (South Africa, 27 October 2004). URL: http://www.eumetsat.int/Home/index.htm (Accessed 14 November 2008).
RAE KJ (2008) Personal communication. Chief Forecaster, National Forecast Centre, South African Weather Service, Bolepi House, Pretoria.

ROUAULT M and RICHARD Y (2003) Intensity and spatial extension of droughts in South Africa at different time scales. Water SA 29 (4) 489-500.

SCHUMACHER RS and JOHNSON RH (2006) Characteristics of U.S. extreme rain events during 1999-2003. Weather Forecasting 21 (1) 69-85.

SINGLETON AT and REASON CJC (2007) Variability in the characteristics of cut-off low pressure systems over subtropical southern Africa. Int. J. Climatol. 27 (3) 295-310.

SAWS (SOUTH AFRICAN WEATHER SERVICE) (1998) Climate of South Africa. Climate statistics 1961-1990. WB42. South African Weather Service, Pretoria, South Africa.

TALJAARD JJ (1996) Atmospheric Circulation Systems, Synoptic Climatology and Weather Phenomena of South Africa. Part 6: Rainfall in South Africa. South African Weather Service Technical Paper 32. South African Weather Service, Pretoria, South Africa.

VIVIERS G and CHAPMAN V (2008) Severe thunderstorm at Johannesburg International Airport (03 December 2004). URL: http://www.eumetsat.int/Home/index.htm (Accessed 14 November 2008).

ZHANG X, HOGG WD and MEKIS E (2001) Spatial and temporal characteristics of heavy precipitation events over Canada. J. Climate 14 1923-1936. 